\title{
PROTECTIVE EFFECTS OF ASCORBIC ACID PRETREATMENT IN A RAT MODEL OF INTESTINAL ISCHEMIA-REPERFUSION INJURY: A HISTOMORPHOMETRIC STUDY
}

Oscar Haruo Higa, Edwin Roger Parra, Alexandre Muxfeldt Ab'Saber, Cecilia Farhat, Rita Higa, and Vera Luiza Capelozzi

Higa OH, Parra ER, Ab'Saber AM, Farhat C, Higa R, Capelozzi VL. Protective effects of ascorbic acid pretreatment in a rat model of intestinal ischemia-reperfusion injury: a histomorphometric study. Clinics. 2007;62(3):315-20.

BACKGROUND:. Ascorbic acid has shown promise in attenuation of intestinal ischemia-reperfusion (I/R) injury. The aim of this study was to determine the protective effects of ascorbic acid on intestinal morphology during IR injury in rats.

MATERIALS AND METHODS:. We examined morphological changes in the small intestine of Wistar rats after (i) 40 minutes of ischemia (I), (ii) ischemia followed by $30 \mathrm{~min}$ of reperfusion (IR), (iii) ischemia with ascorbic acid (IA), (iv) ischemia followed by reperfusion and ascorbic acid (IRA) and (v) in a sham group (S). We used morphometry to evaluate the amount of villous architecture, crypts, necrosis, hemorrhagic infarcts and inflammatory cells at the mesenteric and antimesenteric borders of the small intestine.

RESULTS: Ascorbic acid caused a significant reduction of antimesenteric villous hemorrhagic infarction $(\mathrm{p}<0.05)$ of the small intestine after ischemia followed by reperfusion as well as villous necrosis reduction at both borders after ischemia $(\mathrm{p}<0.05)$. The lesions found in the small intestine were more prominent along the antimesenteric margin.

CONCLUSIONS: Ascorbic acid pretreatment has a protective effect against the intestinal morphological lesions induced by ischemia-reperfusion injury in rats.

KEY WORDS: Small intestine; Ischemia-reperfusion; Morphometric analysis; Ascorbic acid; Ischemia.

\section{INTRODUCTION}

Intestinal ischemia and subsequent reperfusion (IR) injury is encountered in a variety of clinical conditions, including acute mesenteric ischemia, intestinal obstruction, incarcerated hernia, small intestine volvulus, and necrotizing enterocolitis. The consequences of mesenteric ischemia are devastating to the patient and usually result in diarrhoea, malabsorption, short bowel syndrome and even death ${ }^{1}$. In addition, IR injuries have been a key problem with respect to successful or-

Department of Pathology, Sao Paulo University Medical School, Sao Paulo/ SP, Brazil.

Email: vcapelozzi@lim05.fm.usp.br

Received for publication on November 17, 2006

Accepted for publication on December 13, 2006. gan preservation in small intestine transplantation ${ }^{2}$.

The gastrointestinal tract is one of the most sensitive tissues to ischemia and reperfusion ${ }^{3}$. Thus, there is great interest concerning methods to verify protective mechanisms in extensive small intestine lesions that can shorten the patient's life. For the transplantation treatment to be effective, we must identify and protect small intestine morphological changes after IR injuries. In this regard, many authors have studied small intestine morphological aspects to determine what might correlate to the pathogenesis of the resulting injury and protective mechanisms ${ }^{4}$. Because free oxygen radicals are involved in ischemia/reperfusion injuries ${ }^{5,6,7}$ a group of anti-oxidants has been targeted as potential useful protective agents against morphological changes identified after small intestine injuries ${ }^{8}$. Among these, ascorbic acid has 
shown promise. Ascorbic acid is water-soluble with reducing and chelating properties; it thus washes out free radicals produced during ischemia, and scavenges reactive oxidants produced immediately after reperfusion ${ }^{9}$. Nakamura's study demonstrated that ascorbic acid prevents IR injuries ${ }^{10}$, but the quantitation of morphological changes reported is uncertain. In fact, many methods have been proposed to quantify morphological changes induced by IR in organs. Some have used binary cut-points to define the presence of morphological changes. Others have expressed the morphological changes in crosses, and yet, others have expressed them semi-quantitatively ${ }^{11}$. In this study, we assume that ascorbic acid pretreatment has a protective effect against the intestinal morphological lesions induced by ischemia-reperfusion injury in rats. To test the hypothesis, we quantified the intestinal morphological lesions by histomorphometry and herein report our results.

\section{MATERIALS AND METHODS}

\section{Intestinal I/R Injury Model}

This study was approved by the Ethics Committee of the University São Paulo Medical School. The experimental design was as follows: 50 male Wistar rats weighing between 250 and $300 \mathrm{~g}$ were divided in 5 groups ( $\mathrm{n}=10$ in each group): sham (S), ischemia (I); ischemia/ reperfusion (IR), ischemia/ascorbic acid (IA) and ischemia/reperfusion/ascorbic acid (IRA). Animals in the ischemia and ischemia/reperfusion groups received $2 \mathrm{ml}$ of sterile saline solution $(0.9 \% \mathrm{NaCl})$ into the peritoneal cavity one hour before the surgical procedure. The ischemia/ascorbic acid and ischemia/reperfusion/ascorbic acid groups underwent the same experimental procedure but with an intraperitoneal injection of $2 \mathrm{mmol} / \mathrm{kg}$ of ascorbic acid (Sigma Chemical Co St. Louis. Mo. USA) suspended in saline solution (total volume $=2 \mathrm{ml}$ ). The rats were anesthetized with an $80 \mathrm{mg} / \mathrm{kg}$ ketamine intramuscular injection (Dopalen, Agribands of Brazil, Paulínea, $\mathrm{SP}$ ) and $10 \mathrm{mg} / \mathrm{kg}$ of xylazine (Dopaser, Calier Laboratory of Brazil). An abdominal incision was performed to expose the superior mesenteric artery in the ischemia group and occluded for 40 minutes using a micro vascular clamp. The occluding clamp was removed after 40 minutes for a reperfusion period for 30 additional minutes in the ischemia/reperfusion group. Rats in the sham group were submitted to the abdminal incision but not to the occlusion/reperfusion. At the end of each procedure rats were sacrificed and the proximal jejunum was processed using standard histological techniques including forma- lin fixation, dehydration and paraffin embedding, and were subsequently cut in $4 \mu \mathrm{m}$ sections and stained with Haematoxylin and Eosin. The normal intestine sample of the sham group did not undergo artery manipulation.

\section{Morphometric Study}

We performed a morphometric analysis of the mesenteric and antimesenteric small intestine borders. Selection of intestinal compartments to be analyzed as well as cell counts were performed by an investigator blinded to group allocation. An integrating eyepiece with a coherent system made of a 100-point grid consisting of 50 lines of known length coupled to a light microscope was used. At X100 and X400 fractional areas of villous, crypts, necrosis, hemorrhagic infarctions and inflammatory cells were determined by the point-counting technique ${ }^{12}$. We counted all points falling on these components and divided them by the total number of points. We averaged this over 10 non-overlapping microscopic fields in each case to obtain a result as a percentage of measured structures as shown below.

\section{Fractional Area $(\mathrm{A} / \mathrm{A})=\mathbf{Z p}($ struct. $) / Z \mathbf{Z}(\operatorname{sect})$}

where the Fractional Area (A/A) is equal to the number of points overlying villous, crypts, necrosis and inflammatory cells $[\mathrm{Zp}$ (struct)] divided by the total number overlying small intestine tissue $[\mathrm{Zp}(\mathrm{sect})]$. The intra and interobserver variability were less than $10 \%$.

\section{Statistical Analysis}

The normality of the data (Kolmogorov-Smirnov test with Lilliefor's correction) and the homogeneity of variances were tested. One-way analysis of variance (ANOVA) was used to compare the groups. When variances were different, a Dunnet test was applied (global a=5\%), whereas a Tukey test was used for equal variances. Control (ischemia and ischemia/reperfusion) and ascorbic groups (ischemia/ ascorbic acid and ischemia/reperfusion/ascorbic acid) were compared by Student's T test for independent samples. In all instances, the significance level was set at $5 \%$.

\section{RESULTS}

Morphological Changes after Ischemia, Ischemia Reperfusion and Ascorbic Acid Treatment. Figure 1 illustrates the intestinal architecture of the sham, ischemia, IR, and IR/ascorbic acid groups. The intestinal wall of the sham group shows the maintenance of its architecture (Figure 1A and $1 \mathrm{E})$. In contrast, intestinal specimens of animals who 
underwent ischemia or ischemia reperfusion show a distortion of the architecture through the presence of necrosis of the villi (Figure $1 \mathrm{~B}$ and $1 \mathrm{~F}$ ) and a decrease of villi length (Figure 1C and 1G). This contrasts with a degree of protection regarding necrosis and length of the villi, seen in the $\mathrm{I} /$ ascorbic acid and IR/ascorbic acid groups (Figure 1D and $1 \mathrm{H})$. Equally important morphological changes, such as hemorrhagic infarctions, are present at the mesenteric border in ischemia group and at the antimesenteric border in the IR groups (Figure 1I and 1J).
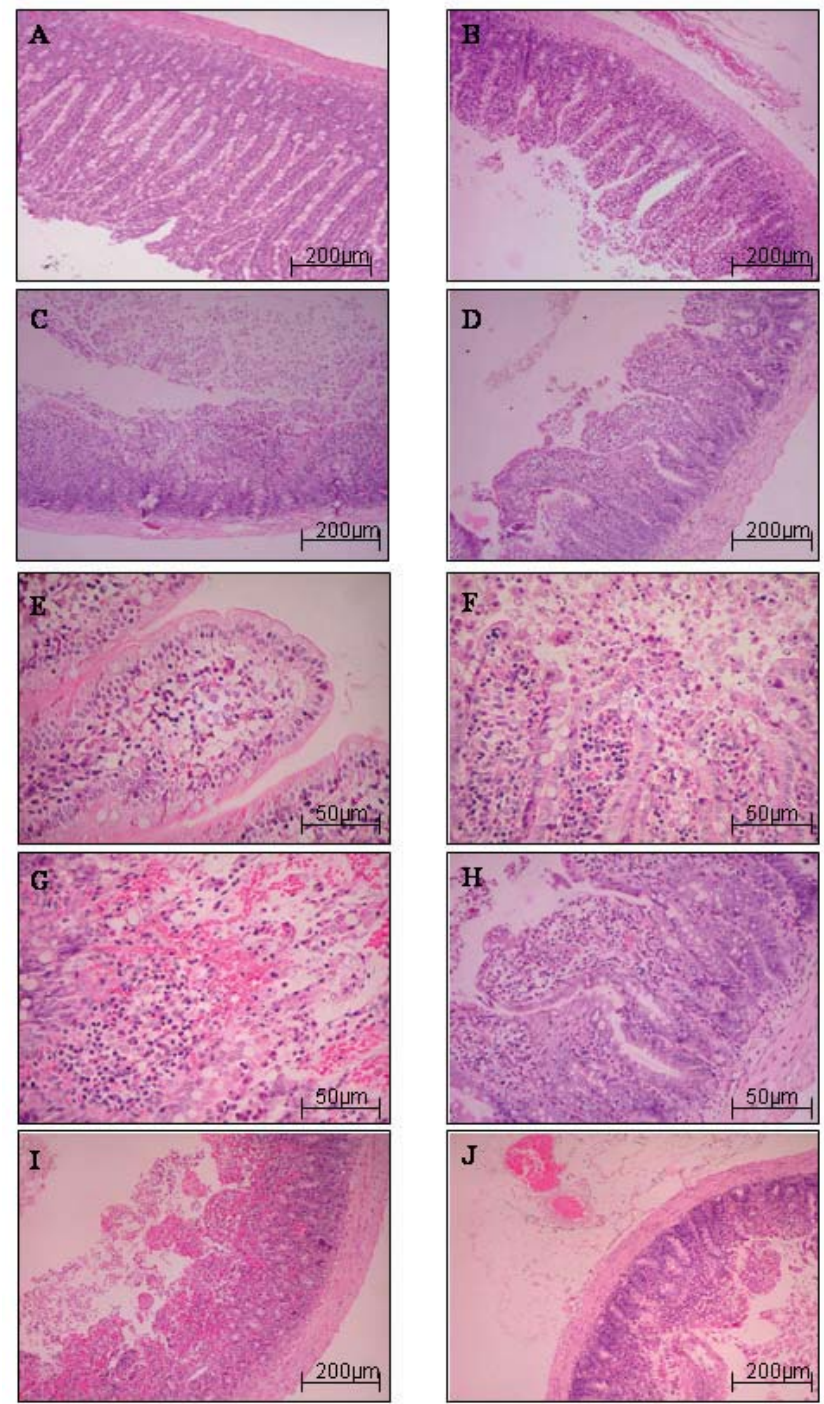

Figure 1. Intestinal architecture of the sham (A), ischemic (B), ischemic/ reperfusion $(\mathrm{C})$ and ischemic/reperfusion/ascorbic acid groups (D), stained with Hematoxilyn and Eosin. Note the maintenance of the architecture of intestine wall in sham group (E). Distortion of the architecture by villous necrosis $(F)$ and decrease of villous $(\mathrm{G})$ are visualized in intestine specimens of animals with ischemia and ischemia reperfusion. In contrast, ischemia/ reperfusion/ascorbic acid treated animals $(\mathrm{H})$ show decrease of villous necrosis and increase in villous cell. Different histoanatomical localization of hemorrhagic infarct was observed for ischemia and ischemia-reperfusion groups. In ischemia groups hemorrhagic infarct was present at the mesenteric border (I) whereas in ischemia-reperfusion groups the antimesenteric border was affected (J).
Morphometric Changes after Ischemia, Reperfusion and Ascorbic Acid Treatment. Graphic illustrations of histological quantitation in the five groups of rats are show in Figures 2A-C. Antimesenteric villi were significantly shorter in the ischemia-reperfusion group when compared to the ischemia group ( $0.34 v s .0 .45 ; \mathrm{p}=0.04)$. The degree of antimesenteric haemorrhagic infarction in the IR group was greater than that observed in the ischemia group $(0.63$ vs. $0.42 ; \mathrm{p}=0.01)$. IR rats presented a greater degree of antimesenteric haemorrhagic infarction when compared to corresponding IR/ascorbic acid rats (0.63 vs. 0.36; $\mathrm{p}=0.009$ ). The small intestine exposed to ischemia presented significantly more mesenteric and antimesenteric villous necrosis, respectively, when compared to I/ascorbic acid ( 0.15 vs. $0.04, \mathrm{p}=0.004 ; 0.32$ vs. $0.19 ; \mathrm{p}=0.01)$. Crypt and inflammatory cells did not show statistical differences among the groups. The main point of these results was the significant difference concerning villi, necrosis and hemorrhagic infarction at the mesenteric and antimesenteric borders (Figure 2A-2B) and the protective effect of ascorbic acid on the morphological changes found in the IR group.

\section{DISCUSSION}

The most likely reason why abdominal surgical procedures and trauma are associated with high morbidity and mortality is the fact that ischemia can easily injure the intestine, and subsequent reperfusion can increase the damage to the mucosa. Park et al ${ }^{13}$ demonstrated that most of the tissue damage produced by the widely employed regional hypotension model occurs at the time of the reperfusion ${ }^{13,14}$. Other organs may also be affected ${ }^{15}$ The question of interest is whether pretreatment has a protective effect and whether additional information gathered from small intestine tissue analysis can help us identify the extension and severity of the morphological changes due to ischemia. In this context, experimental therapeutic measures have been successfully tested to attenuate intestinal ischemia-reperfusion injury in animal models including ischemic preconditioning ${ }^{16,17}$; anti complement ${ }^{18}$; anti leukocyte ${ }^{19}$; anti-inflammatory therapies ${ }^{20,21}$ with fluorocarbons, glutamine and glycine supplementation ${ }^{22}$; enteral feeding ${ }^{23}$ and antioxidants ${ }^{24}$. Among the antioxidants, ascorbic acid ${ }^{10}$ has been specially noted. In these situations, a decreased expression of IR injury detected by histopathological analysis has been associated with favorable outcome of the IR injury. Thus, for all reasons, it should not be surprising that ascorbic acid pretreatment has a protective effect on intestinal ischemia-reperfusion injury in rats; our results confirm this point and stress the 
importance of a quantitative assessment of injury after small intestine ischemia.

We have recently shown the objective importance of
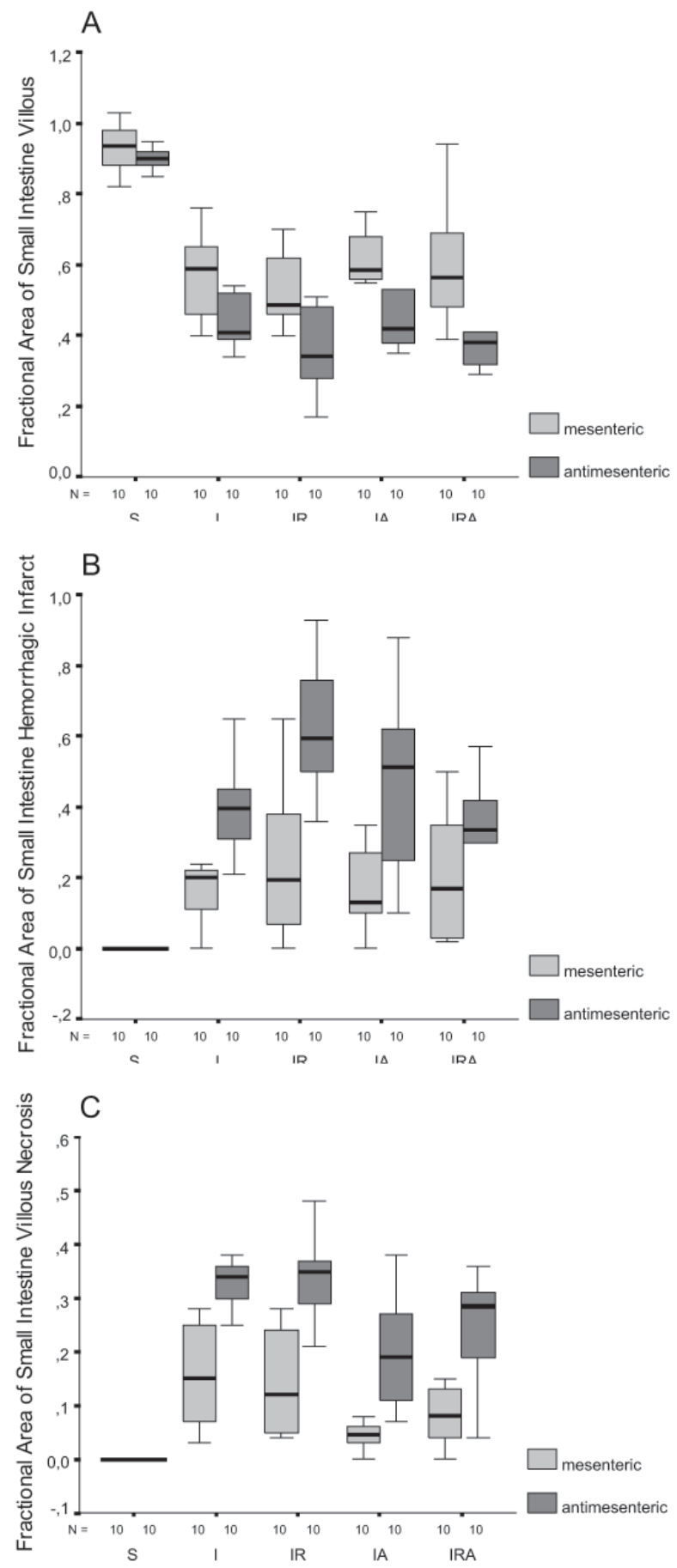

GROUPS

IR=ischemia/reperfusion; IRA=ischemia/reperfusion/ascorbic acid, I=ischemia; $\mid \mathrm{A}=$ =ischemia/ascorbic; $\mathrm{S}=$ sham

Figure 2. Fractional area of anti mesenteric and mesenteric villous (A), hemorrhagic infarct (B), villous necrosis (C) according to the sham, ischemia, ischemia/reperfusion, ischemia/ascorbic acid and ischemia/reperfusion/ ascorbic acid. quantification of histopathological parameters ${ }^{25}$ Is this study, we have confirmed and quantified the protective effects of ascorbic acid pretreatment in a rat model of intestinal ischemia-reperfusion injury using an objective histomorphometric method. Subjectivity is minimized and, equally important, inter and intra-observer variability decreased. The method also facilitates the comparison of the obtained results and allows evaluation of different intervention mechanisms with precision.

We found that necrotizing changes after small intestine ischemia and reperfusion, without ascorbic acid protection, was associated with increased villous necrosis and hemorrhagic infarct. Thus, for instance, villous necrosis extension was significantly related to small intestine ischemia and reperfusion, and ascorbic acid treatment reduced the extension of necrosis, and this was also significantly related to most of the contramesenteric intestinal border. Most interesting was the quantitative relationship we found between ascorbic acid treatment and mucosal hemorrhagic infarct. Similar findings were reported by Nakamura and colleagues ${ }^{10}$. Nilsson et al ${ }^{17}$ have proposed the countercurrent $\mathrm{O}_{2}$ exchange hypothesis to explain the marked susceptibility of intestinal villi to ischemia. According to this hypothesis, the villus tips become virtually anoxic in spite of an unaltered mucosal blood flow due to shunting of oxygen between the arterioles and venules at the base of the villus. Support for this theory is provided by the observation that ischemic injury to the small bowel is most severe at the tip and is attenuated by intraluminal perfusion with oxygenated saline ${ }^{26}$. A variety of associations between ascorbic acid and IR injury has been described recently ${ }^{27-31}$. Cizova et $\mathrm{al}^{27}$ demonstrated that the ascorbic and uric acid concentrations increased generally after IR in comparison to intact controls, but this increase was not sufficient to prevent lipid peroxidation in serum and intestinal mucosa. In short, the small molecular antioxidants measured did not contribute to the phenomenon of ischemic preconditioning. In this context the increased ascorbic acid may contribute to the improvement of the IR injury. Now, we have quantitatively demonstrated that in small intestine injury there is an association between villous necrosis and hemorrhagic infarct, and that ascorbic acid pretreatment attenuates these alterations; to the best of our knowledge, this is the first report of this association by quantitative assessment. The association between villous necrosis and hemorrhagic infarct to ascorbic acid treatment suggest that small intestine ischemia manufactures and secretes higher levels of free radicals, all of which facilitates cellular injury and tissue destruction ${ }^{5,16,17}$. Thus, increased amount of villous 
necrosis may be more of a primary event, and increased hemorrhagic infarct more of a secondary event. Regardless of the mechanism, quantitative assessment of IR injury provides important information in small intestine ischemia

We have also showed that in ischemia-reperfusion injuries there is an improvement of hemorrhagic infarction at the antimesenteric border after ascorbic acid treatment and to the best of our knowledge this is the first report of this association using a quantitative approach. Whereas only three prior studies with ascorbic acid were able to show any significant relationship between morphological changes and small intestine ischemia-reperfusion ${ }^{10,23,24}$ our results show that the quantitative assessment of histopathological parameters provides more information than the qualitative pathological assessment. Furthermore, we describe improvement of hemorrhagic infarction at the antimesenteric border after ascorbic acid treatment and again, to the best of our knowledge this is the first report of this association using a quantitative approach. Thus, a quantitative assess- ment of intestinal ischemia offers the potential to guide the control of risk in patients after surgical resection of small intestine.

In summary, this study demonstrated the consequences of small bowel ischemia in a rat model, with and without pre-treatment with ascorbic acid, by a quantitative pathologic/histomorphometric study. Ischemia-reperfusion resulted in more injury than ischemia alone and that pretreatment with ascorbic acid resulted in protection, especially in the endpoints of hemorrhagic infarction and necrosis. This finding raises the possibility of using ascorbic acid before surgical procedures that involve IR periods. Some limitations of this study should be highlighted: experimental studies other than histological will be required to verify if pre-treatment leads to better outcome in terms of animal survival. Enzyme function must be measured, and a dose-response injury methodology will have to be employed. Long term follow-up, using this model with examination of the bowel one or two days later will probably be more convincing of its protective effects.

\section{RESUMO}

Higa OH, Parra ER, Ab'Saber AM, Farhat C, Higa R, Capelozzi VL. Efeito protetor do pré-tratamento com ácido ascóbico em modelo experimental de isquemia-reperfusão intestinal: um estudo histomorfométrico. Clinics. 2007;62(3):315-20.

INTRODUÇÃO: O ácido ascórbico tem se mostrado como um agente promissor na atenuação da lesão causada pela isquemia/reperfusão (IR). O objetivo deste estudo foi determinar os efeitos protetores do ácido ascórbico na morfologia intestinal durante a IR em ratos.

MATERIAL E MÉTODOS: Examinamos alterações morfológicas no intestino delgado de ratos do tipo Wistar. Após 40 minutos de isquemia (I), isquemia seguida de reperfusão (IR), isquemia com tratamento com ácido ascórbico (IA), isquemia seguida por 30 minutos de reperfusão e tratamento com ácido ascórbico (IRA) e do grupo sham (S). Utilizamos a morfometria para avaliar quantitativamente a arquitetura dos vilos da mucosa intestinal, criptas intestinais, necrose, hemorragia, células inflamatórias nas bordas mesentéricas e antimesentéricas do intestino delgado.

RESULTADOS: O ácido ascórbico causou uma redução significativa $(\mathrm{p}<0,05)$ no infarto hemorrágico dos vilos intestinais da borda antimesentérica do intestino delgado após isquemia seguida por reperfusão, bem como redução da necrose dos vilos em ambas as bordas após a isquemia $(p<0.05)$. As lesões presentes no intestino delgado foram mais proeminentes na borda antimesentérica.

CONCLUSÕES: O pré-tratamento com ácido ascórbico atenuou ou reduziu significativamente as alterações morfológicas no intestino delgado induzidas pela isquemia-reperfusão.

UNITERMOS: Intestino delgado, Isquemia reperfusão, Análise morfométrica, Acido ascórbico, Isquemia. 


\section{REFERENCES}

1. Aldemir M, Gurel A, Buyukbayram H, Tacyildiz I. Aldemir M, Gurel A, et al. The effects of glucose-insulin-potassium solution and BN 52021 in intestinal ischemia-reperfusion injury. Vasc Endovascular Surg. 2003; 37 (5): $345-51$.

2. Nakao M, Hirata Y, Taguchi T, Yamada T, Rahman MS, Suita S. Energy metabolism and xantine oxidase enzyme system during ischemia reperfusion in rat small intestine. Transplant. Proc.1996; 28 (5): 2614.

3. Moj•ís $\mathrm{J}$, Hvišèová $\mathrm{K}$, Germanová $\mathrm{D}$, Bukovièová $\mathrm{D}$, Mirossay L: Protective effect of quercetin on ischemia/reperfusion-induced gastric mucosal injury in rats. Physiol Res 50: 501-506, 2001.

4. Collard CD, Gelman S. Pathophysiology, clinical manifestations, and prevention of ischemia-reperfusion injury.Anesthesiology. 2001; 94 (6):1133-8.

5. Granger DN, Hollwarth ME, Parks DA. Ischemic-reperfusion injury: role of oxygen-derived free radicals. Acta Physiol Scand Suppl. 1986; 548: 47-63.

6. McCord JM. Oxygen-derived free radicals in postischemic tissue injury. N. Engl. J. Of Med. 1985; 312 (3): 159-63. Review.

7. Hirata Y, Taguchi T, Nakao M, Yamada T, Hirose R, Suita S. The relationship between the adenine nucleotide metabolism and the convertion of xantine oxidase enzyme system in ischemia-reperfusion of the rat small intestine. J of Pediatric Surgery. 1996; 31 (9): 1199204.

8. Finkelstein I, Toledo-Pereyra LH, Castilho M, Castellanos J. Comparative analysis of pharmacological agents following small intestine ischemia. Transplant Proc. 1988; 20 (5):1043-4.

9. Cathcart RF. 3rd. Vitamin C: The nontoxic, nonrate-limited, antioxidant free radical scavenger. Med Hypotheses.1985; 18 (1): 61-77.

10. Nakamura M, Ozaki M, Fuchinoue S, Teraoka S, Ota K. Ascorbic acid prevents ischemia-reperfusion injury injury in the rat small intestine. Transpl. Int. 1997; 10 (2):89-95.

11. Quaedackers JS, Beuk RJ, Bennet L, Charlton A, oude Egbrink MG, Gunn AJ, et al. An evaluation of methods for grading Histologic Injury following ischemia/reperfusion of the small bowel. Transplant. Proc.2000; 32 (6): 1307-10.

12. Gundersen HJ, Bendtsen TF, Korbo L, Marcussen N, Moller A, Nielsen $\mathrm{K}$, et al. Some new, simple and efficient stereological methods and their use in pathological research and diagnosis. APMIS. 1988; 96 (5):37994.

13. Parks DA, Granger DN. Contributions of ischemia and reperfusion to mucosal lesion formation. Am J Physiol. 1986; 250(6 Pt 1): G749-53.

14. Kong SE, Blennerhassett LR, Heel KA, McCauley RD, Hall JC. Ischaemia-reperfusion injury to the intestine. Aust. N. Z. J. Surg. 1998; 68 (8): 554-61.

15. Arruda MJC de, Poggetti RS, Fontes B, Younes RN, Souza Jr. AL, Birolini D. Intestinal ischemia/reperfusion induces bronchial hyperreactivity and increases serum TNF-alpha in rats. Clinics. 2006;61:21-28.

16. Mallick IH, Yang WX, Winslet MC, Seifalian AM. Ischemia-reperfusion injury of the intestine and protective strategies against injury. Digestive Diseases and Sciences. 2004 49(9):1359-77.
17. Nilsson UA, Schoenberg MH, Aneman A, Poch B, Magadum S, Beger HG, et al. Free radicals and pathogenesis during ischemia and reperfusion of the cat small intestine. Gastroenterology. 1994, 106 (3): 629-36.

18. Arumugam TV, Shiels IA, Woodruff TM, Reid RC, Fairlie DP, Taylor SM. Protective effect of a new $\mathrm{C} 5$ a receptor antagonist against ischemiareperfusion injury in the rat small intestine. J. Surg. Res. 2002; 103 (2): 260-7.

19. Stojadinovic A, Smallridge R, Nath J, Ding X, Shea-Donohue T. Antiinflammatory effects of $\mathrm{U} 4359 \mathrm{~F}$ in a rat model of intestinal ischemia/ reperfusion injury. Critical Care Medicine. 1999; 27 (4): 764-70.

20. Kawata K, Takeyoshi I, Iwanami K, Sunose Y, Aiba M, Ohwada S, et. al. Effect of FR167653 on small bowel ischemia-reperfusion injury in dogs. Digestive Diseases and Sciences. 1999; 44 (11): 2334-43.

21. Arumugam TV, Shiels IA, Margolin SB, Taylor SM, Brown L. Pirfenidone attenuates ischemia-reperfusion injury in the rat small intestine. Clin Exp Pharmacol Physiol. 2002; 29 (11): 996-1000.

22. Lee MA, Mccauley RD, Kong SE, Hall JC. Pretreatment with glycine reduces the severity of warm intestinal ischemic-reperfusion injury in the rat. Ann. Plastic Surg. 2001; 46 (3): 320-6.

23. Salehi P, Madsen K, Zhu J, Castillo E, Avila J, Lakey JR, et al. Alleviating ischemia-reperfusion injury in small bowel. Am. J. Transplant.2004; 4 (5): 728-37.

24. Bilbao J, Garcia-Alonso I, Portugal V, Barcelo P, Ortiz J, Mendez J. Therapeutic usefulness of antioxidant drugs in experimental intestinal reperfusion syndrome. Rev Esp Enferm Dig. 1991; 80 (4): 237-41.

25. Matos LL de, Stabenow E, Tavares MR, Ferraz AR, Capelozzi VL, Pinhal MA da S. Immunohistochemistry quantification by a digital computerassisted method compared to semiquantitative analysis. Clinics. 2006;61:417-424.

26. Byrka-Owczarek K, Steplewska-Mazur K, Krason M, Bohosiewicz J, Koszutski T, Wojtynek G. The evaluation of the protective action of antioxidants on small intestine of rabbits experimentally injured by ischemia and reperfusion. J Pediatr Surg. 2004; 39 (8): 1226-9.

27. Cizova H, Papezikova I, Kubala L, Lojek A, Ciz M. Increased antioxidant capacity of serum did not prevent lipid peroxidation in the intermittent ischemia-reperfusion of rat small intestine. Dig Dis Sci. 2006; 51 (4): $657-61$.

28. Mallick IH, Yang W, Winslet MC, Seifalian AM. Protective effects of ischemic preconditioning on the intestinal mucosal microcirculation following ischemia-reperfusion of the intestine. Microcirculation. 2005; 12 (8):615-25.

29. Stefanutti G, Pierro A, Vinardi S, Spitz L, Eaton S. Moderate hypothermia protects against systemic oxidative stress in a rat model of intestinal ischemia and reperfusion injury. Shock. 2005; 24 (2):159-64.

30. De Tata V, Brizzi S, Saviozzi M, Lazzarotti A, Fierabracci V, Malvaldi $\mathrm{G}$, et al. Protective role of dehydroascorbate in rat liver ischemiareperfusion injury. J Surg Res. 2005; 123 (2):215-21.

31. Mallick IH, Yang WX, Winslet MC, Seifalian AM. Pyrrolidine dithiocarbamate reduces ischemia-reperfusion injury of the small intestine. World J Gastroenterol. 2005; 11 (46):7308-13. 